\title{
Kajian Sanitasi Total Berbasis Masyarakat (STBM) di Lingkungan Kumuh Kota Palembang: Studi Kualitatif
}

\author{
Nur Azizah, Yustini Ardillah", Indah Purnama Sari, Yuanita Windusari \\ Fakultas Kesehatan Masyarakat Universitas Sriwijaya, Indralaya Indah, Kecamatan Indralaya Utara, Kabupaten Ogan Ilir, \\ Palembang 30128, Indonesia \\ *Corresponding author: yustini_ardillah@fkm.unsri.ac.id
}

Info Artikel:Diterima 8 November 2019 ; Disetujui 17 Maret 2021 ; Publikasi Oktober 2021

Cara sitasi (Vancouver): Azizah N, Ardillah Y, Sari IP, Windusari Y. Kajian Sanitasi Total Berbasis Masyarakat (STBM) di Lingkungan Kumuh Kota Palembang: Studi Kualitatif. Jurnal Kesehatan Lingkungan Indonesia [Online]. 2021 Oct;20(2):65-73. https://doi.org/10.14710/jkli.20.2.65-73.

\begin{abstract}
ABSTRAK
Latar Belakang: Daerah kumuh terluas di Palembang yaitu di Kecamatan Sebrang Ulu 2 dengan luas wilayah kumuh 459,9 Ha dari besar wilayah $873 \mathrm{Ha}$, jumlah penduduk 100.575 dan kepadatan penduduk mencapai 174,61 /Ha dengan berbagai tingkat kekumuhan mulai dari kumuh sedang hingga berat. Tujuan penelitian ini adalah untuk mengkaji dan menggambarkan pilar-pilar STBM di lingkungan kumuh Kecamatan Seberang Ulu II Kota Palembang.

Metode: Penelitian ini merupakan penelitian kualitatif dengan metode deskriptif. Informasi didapatkan dari wawancara mendalam dan photovoice. Informan dalam penelitian ini berjumlah 13 orang yang ditetapkan secara langsung oleh peneliti (purposive sampling) berdasarkan kriteria yang dibutuhkan terdiri dari 11 orang informan kunci dan 2orang informan biasa. Analisis data yang digunakan adalah content analysis. Uji validitas yang dilakukan melalui triangulasi sumber, metode, dan data.

Hasil Penelitian: Hasil penelitian menunjukan pilar pertama yaitu Stop Buang air besar Sembarangan masyarakat telah memiliki jamban baik milik sendiri maupun sharing, dengan konstruksi bangunan lengkap maupun tidak berseptic tank untuk yang di pinggiran sungai. Pilar kedua berupa Cuci Tangan Pakai Sabun masyarakat masih menganggap cuci tangan dengan air saja sudah cukup. Pilar Ketiga yaitu Pengelolaan Air Minum dan Makanan Rumah Tangga masyarakat telah melakukan pengelolaan dengan baik karena mereka menyadari dampak kesehatan jika makanan dan air minum yang dikonsumsi tidak bersih. Pilar keempat yaitu pengamanan sampah rumah tangga masyarakat belum melakukan pengamanan dan masih ada yang membuang sampah kesungai. Pilar kelima yaitu pengamanan air limbah rumah tangga masyarakat cenderung langsung membuang air limbah langsung kesungai, tanah, ataupun drainase.

Simpulan: Dapat disimpulkan bahwa sanitasi dasar yang mencakup 5 pilar STBM dari kelimanya tidak semuanya dilaksanakan dengan optimal dikarenakan masyarakat belum mengetahui mengenai STBM juga kegiatan yang dilakukan telah menjadi kebiasaan dan sulit untuk dirubah.
\end{abstract}

Kata kunci: Kualitatif; Sanitasi Total Berbasis Masyaraka (STBM); Slum Area.

\section{ABSTRACT}

Title: Study of Community Lead Total Sanitation in Slum Area, Palembang City: Qualitative Study

Background: The widest slum area in Palembang was in Seberang Ulu 2 District with slum area 459,9 ha of the total area $873 \mathrm{ha}$, the population were 100.575 and the population density reach 174,61/ha with various levels of slum from medium to heavy slum. The purpose of this study was to assessed and described the pillars STBM in slum area Seberang Ulu II District Palembang. 
Methods: This research was qualitative descriptive method. Information collected through in-depth interviews and photovoice. The informants in this study were 13 people. Analysis of the data used content analysis. Validity test used through triangulation of sources, methods, and data.

Result: The results of the study showed that the first pillar was SBS, the community had toilets either owned or shared, with the construction of a complete building or not using septic tank in the riverside. The second pillar was CTPS people still think washing hands with water was sufficient. The third pillar was PAMM-RT the society was managing well because they were aware of the health impact if the food and drink consumed water was not clean. The fourth pillar was household waste management the community has not carried out security for waste and there were still people who threw the garbage into the river. The fifth pillar was household waste water management people tend to throw the wastewater directly into the river, land, or drainage.

Conclusion: It can be concluded that the basic sanitation that includes five pillars STBM has not gone well enough.

Keywords: Qualitative; Slum area; Community Based Total Sanitation (CLTS).

\section{PENDAHULUAN}

Menurut Kepala Bappenas tahun 2017 Indonesia menduduki peringkat ke-2 di dunia sebagai negara dengan sanitasi terburuk setelah India, hal tersebut dikarenakan sebagian besar masyarakat melakukan BAB sembarangan di berbagai tempat. Isu sanitasi tersebut yang menjadi tanggung jawab semua pihak karena erat hubungannya dengan kegiatankegiatan manusia. Berbagai macam penyakit dapat ditimbulkan oleh sanitasi yang buruk. Situasi ini membuat kampanye sanitasi sehat harus terus digalakkan di masyarakat. ${ }^{1}$

Upaya untuk memperkuat pembudayaan hidup bersih dan sehat, mencegah penyebaran penyakit berbasis lingkungan, meningkatkan kemampuan masyarakat, serta mengimplementasikan komitmen Pemerintah untuk meningkatkan akses air minum dan sanitasi dasar yang berkesinambungan, pada tahun 2008 diluncurkanlah Strategi Nasional Sanitasi Total Berbasis Masyarakat yang ditetapkan dengan Keputusan Menteri Kesehatan. Sanitasi Total Berbasis Masyarakat merupakan suatu program dengan pendekatan kepada masyarakat untuk mengubah perilaku higienis dan sanitasi melalui pemberdayaan masyarakat tanpa bantuan subsidi yang mencakup 5 pilar, yaitu stop BABs (Buang Air Besar sembarangan), Cuci Tangan Pakai Sabun (CTPS), Pengelolaan Air dan Makanan yang Aman di Rumah Tangga (PAM RT), Pengelolaan Sampah Rumah Tangga (PS RT) dan Pengelolaan air limbah rumah tangga (PAL RT) dengan aman. ${ }^{2}$ Program STBM ini memiliki sasaran yaitu semua masyarakat yang ada dilingkungan tertentu dengan prioritas utama dari program STBM ini adalah pada daerah yang jauh dari pusat kota terutama daerah yang mempunyai topografi yang sangat memungkinkan untuk melakukan tindakan tidak higienis atau tidak sehat serta daerah kumuh. ${ }^{3}$

Kota Palembang mempunyai luas wilayah sebesar 99.826 Ha dengan jumlah penduduk 1.602.071 jiwa dan kepadatan penduduk 16,049 jiwa/ Ha. Kota yang dialiri oleh sungai musi ini membuat masyarakat bermukim di tepi sungai, pada umumnya pemukiman tersebut terdiri dari bangunan berbentuk rumah panggung, berbahan utama lantai kayu, dinding kayu dan atap seng dengan kerapatan bangunan cukup tinggi dan letak tidak beraturan satu sama lain dengan jalan kecil berupa lorong-lorong. ${ }^{4}$ Kondisi lingkungan sekitar rumah dengan prasarana drainase kurang memadai, fasilitas pengolahan sampah yang kurang memadai dan penggunaan air sungai untuk air seharihari membuat lingkungan cenderung kumuh, namun terdapat pula permukiman dengan kerapatan bangunan cukup tinggi dan kondisi lingkungan yang kurang memadai namun tidak berada di pinggiran sungai. Penelitian terdahulu di daerah kumuh pinggiran Sungai Musi ini menemukan bahwa perkembangan penyakit menular tertinggi diantara kecamatan lainnya dan penyakit tersebut dipengaruhi oleh faktor sanitasi lingkungan. ${ }^{5}$ Kondisi lingkungan di daerah kumuh tersebut seharusnya bisa diatasi apabila program STBM telah diimplementasikan dengan maksimal. Berdasarkan fakta yang telah diuraikan di atas, penelitian ini bertujuan untuk mengkaji dan menggambarkan pilar pilar Sanitasi Total Berbasis Masyarakat di Lingkungan Kumuh Kota Palembang.

\section{MATERI DAN METODE}

Penelitian ini merupakan penelitian kualitatif dengan metode deskriptif untuk mengkaji dan menggambarkan 5 pilar Sanitasi Total Berbasis Masyarakat (STBM) di lingkungan Kumuh Kecamatan Seberang Ulu II Kota Palembang tahun 2019. Informasi didapatkan dari wawancara mendalam dan photovoice. Informan dalam penelitian ini berjumlah 13 orang yang terdiri dari 11 informan kunci dan 2 informan biasa yang dipilih menggunakan teknik sampling secara purposive sampling berdasarkan pertimbangan tertentu yang telah dibuat oleh peneliti seperti informan yang memiliki kewenangan dalam penerapan kegiatan, informan yang mengetahui pelaksanaan kegiatan, masyarakat yang berada di pinggiran sungai dan jauh dari sungai, serta bersedia menjadi informan. Analisis data yang digunakan adalah content analysis yaitu menggunakan tabel/matrik berisikan hasil ringkasan dari wawancara mendalam dan observasi yang dilakukan dilapangan 
kemudian dianalisis dan disajikan dalam bentuk narasi untuk di interpretasikan. Uji validitas yang dilakukan melalui triangulasi sumber dengan melakukan cross check ulang informasi yang didapatkan dari informan yang satu dengan informan yang lain, juga triangulasi metode dengan menggunakan antara lain wawancara mendalam, observasi dan photovoice.

\section{HASIL DAN PEMBAHASAN}

Karakteristik Informan

Tabel 1. Karakteristik Informan Kunci

\begin{tabular}{ccccccc}
\hline No & $\begin{array}{c}\text { Kode } \\
\text { Informan }\end{array}$ & Umur & $\begin{array}{c}\text { Jenis } \\
\text { kelamin }\end{array}$ & Pendidikan & $\begin{array}{c}\text { Lama } \\
\text { Bekerja }\end{array}$ & Jabatan / Pekerjaan \\
\hline 1 & IK 1 & 55 & Perempuan & D-3 & 32 tahun & Petugas sanitarian Puskesmas taman \\
& & & & & 5 tahun & Kepala Seksi BMK Kelurahan 16 Ulu \\
2 & IK 2 & 54 & Perempuan & S-1 & Sekretaris Lurah Tangga Takat \\
\hline
\end{tabular}

\begin{tabular}{ccccccc}
\hline No & $\begin{array}{c}\text { Kode } \\
\text { Informan }\end{array}$ & Umur & $\begin{array}{c}\text { Jenis } \\
\text { kelamin }\end{array}$ & $\begin{array}{c}\text { Pekerjaan Kepala } \\
\text { Keluarga }\end{array}$ & $\begin{array}{c}\text { Jumlah } \\
\text { Keluarga }\end{array}$ & Lama Tinggal \\
\hline 1 & IK 4 & 45 tahun & Perempuan & Becak & 9 orang & 45 tahun \\
2 & IK 5 & 25 tahun & Perempuan & Buruh & 2 orang & 25 tahun \\
3 & IK 6 & 43 tahun & Perempuan & Buruh Baja Ringan & 4 orang & 18 tahun \\
4 & IK 7 & 43 tahun & Perempuan & Buruh & 10 orang & 43 tahun \\
5 & IK 8 & 45 tahun & Perempuan & Guru & 5 orang & 45 tahun \\
6 & IK 9 & 38 tahun & Perempuan & Buruh Cuci & 4 orang & 18 tahun \\
7 & IK 10 & 39 tahun & Perempuan & $\begin{array}{c}\text { Buruh } \\
\text { Tukang Becak }\end{array}$ & 5 orang & 27 tahun \\
8 & IK 11 & 30 tahun & Perempuan & 5 tahu \\
\hline
\end{tabular}

Tabel 2. Karakteristik Informan Biasa

\begin{tabular}{ccccccc}
\hline No. & $\begin{array}{c}\text { Kode } \\
\text { Informan }\end{array}$ & Umur & $\begin{array}{c}\text { Jenis } \\
\text { kelamin }\end{array}$ & Pendidikan & Jabatan / Pekerjaan & $\begin{array}{c}\text { Lama } \\
\text { Bekerja }\end{array}$ \\
\hline 1 & IB 1 & 45 tahun & Perempuan & SMA & Ketua Rt Tangga Takat & 9 tahun \\
2 & IB 2 & 49 tahun & Laki Laki & S-1 & Ketua Rt 54 16 Ulu & 9 tahun \\
\hline
\end{tabular}

Hasil penelitian tentang STBM di lingkungan kumuh Kecamatan Seberang Ulu II Kota Palembang adalah seperti pernyataan berikut berikut :

“...sosialisasi kemasyarakat baru 2017, itu pun hanya ee... kelurahan sentosa kita punya 3 kelurahan yang lain baru mau tahun ini 16 ulu sama tangga takat kita udah ada schedulenya. masyarakat sendiri belum mengetahui tentang stbm karena belum dilakukan sosialisasi tadi, untuk yang di sentosa kita ke binsek dulu ke pemuka masyarakat sosialisasinya di kelurahan jadi yang hadir itu e.. tokoh masyarakat rt rw kader sama ya kader itulah, setelah itu kita turun terus kita survey ke masyarakatnya...."(IK 1)

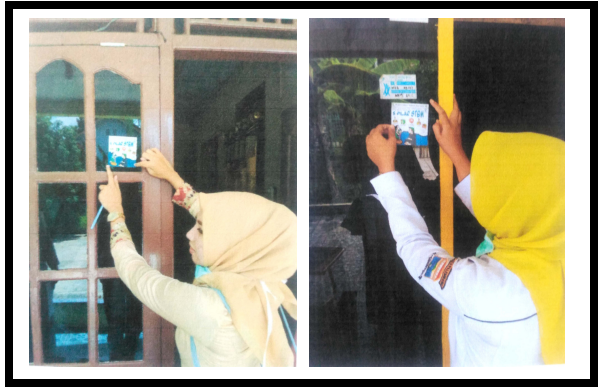

Gambar 1. Stiker Pendataan STBM

Pelaksanaan pilar pertama Sanitasi Total Berbasis Masyarakat berupa Stop Buang Air Besar Sembarangan dapat tergambarkan seperti pernyataan berikut :

“... kalau yang ditangga takat bantaran sungai itu parah.. mereka mau bikin septic tank susah kalau tangga takat itu, kalau yang di 16 ulu itu belum 100 $\%$ tapi prosentasenya udah baik masalah jamban, sentosa juga hasil ini tadi untuk yang OD 1,25\%..." (IK 1) 


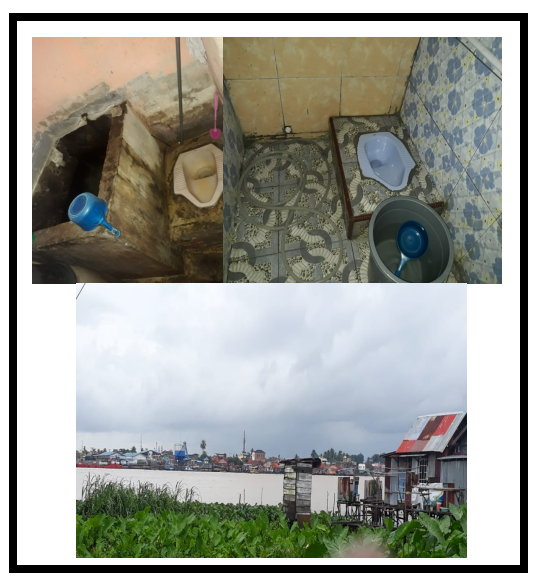

Gambar 2. Jamban Masyarakat

Pelaksanaan pilar kedua Sanitasi Total Berbasis Masyarakat berupa Cuci Tangan Pakai Sabun dapat tergambarkan seperti pernyataan berikut : “...gek ye lah agak lupo padahal waktu tu diajari waktu tu katonyo pagi sebelom kito sarapan cuci tangan, waktu nak makan nah nyuci tangan jugo ado caronyo kami kemaren tu diajari kan dari sini sini tu nah mak itu kami tu, pernah ado itu apo yang cak cak inilah nah lah itu lah lamo itu setaon lewat sudah pas kami kan posyandu jadi kepalangan dio tu kan di posyandu datangnyo kadang kebeneran. Misalnyo pas kito nak makan dak cuci tangan biso saket perot, jadi kalu nyuci tangan pasti make sabun kami ini pokoknyo se apo bae itu harus pake sabun abes buang aer jugo cuci tangan pake sabon diajari galo teros itu, nak makan balek sekolah cuci tangan pake sabun baru makan naah.. namonyo penyaket banyak anehaneh penyaket sekarang." (IK 6)

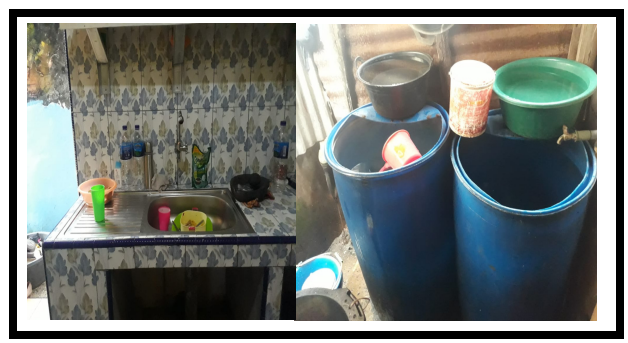

Gambar 3. Sarana CTPS

Pelaksanaan pilar ketiga Sanitasi Total Berbasis Masyarakat berupa Pengolahan Air Minum dan Makanan Rumah Tangga dapat tergambarkan seperti pernyataan berikut :

"kalo ibu ledeng tu diembek dimasukke ember kan, sudah lah diinepken 2 malem 3 malem baru direbos, beli bahan makanan yo diwarung, Kalo milih ikan kan yo yang seger sayur sayur kan yang seger jadi idak do yang ini kalo ikan kan kalo dak seger idak enak dimasaknyo jadi harus seger. Biasonyo beli itu untuk sekali masak tula langsung dimasak idak pernah disimpen disini kan warung sayur tiap hari. Sudah masak simpennyo dalem lemari gerobok, kalu nasi dikukus jadi sudah masak tetep di tempat kukusan..." (IK 9)

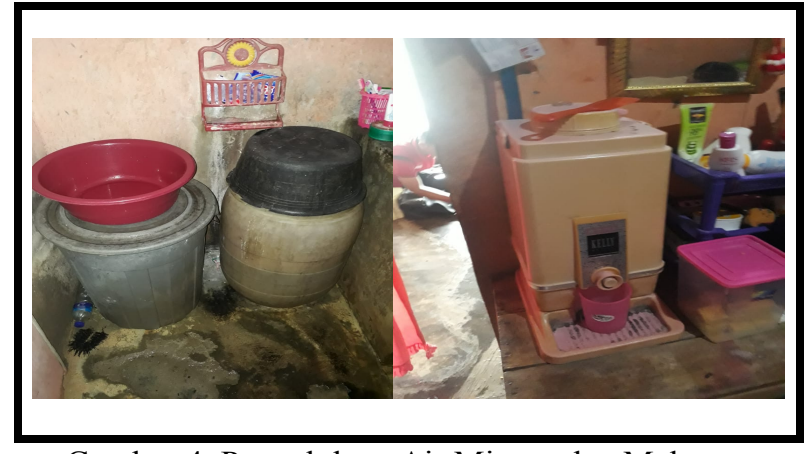

Gambar 4. Pengelolaan Air Minum dan Makanan Rumah Tangga

Pelaksanaan pilar keempat Sanitasi Total Berbasis Masyarakat berupa Pengamanan Sampah Rumah Tangga dapat tergambarkan seperti pernyataan berikut :

“... kalau untuk tempat sampah sebenarnya sudah tersedia , tapi jumlahnya kurang jadi kalo tempo hari banyak yah.. sekarang ga ada lagi 4 yang sudah hilang, jadi sekarang tinggal 1 yang berfungsi didepan sentosa itu dengan jumlah yang kurang dan ditambah lagi kurangnya kesadaran masyarakat, masih ada yang open dumping, ada yang dibakar juga ada seedikit yang dibikin kompos itu baru sedikit. Ada yang dibawa sendiri ke tps ada yang langganan yah ada petugas sampah yang dibayar ada yang dibawa sendiri ke tps gitu..." (IK 1)

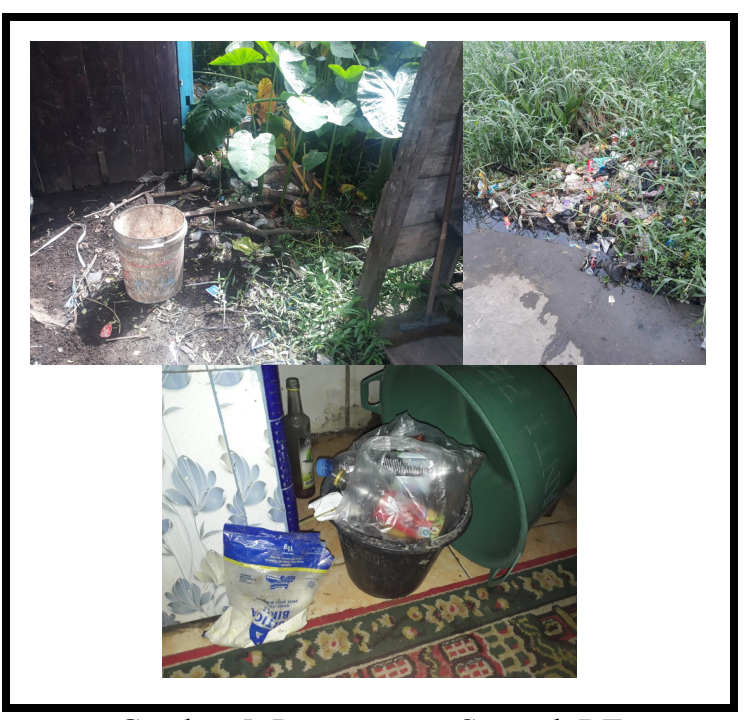

Gambar 5. Pengamanan Sampah RT

Pelaksanaan pilar kelima Sanitasi Total Berbasis Masyarakat berupa Pengamanan Air Limbah Rumah Tangga dapat tergambarkan seperti pernyataan berikut :

"...saluran limbah cair itu masih saluran terbuka belum ada yang khusus, spal yah belum ada yang khusus paling-paling nanti ke riol umum begitu ada 
yang dibuang ke drainase kalau yang dibantaran sungai itu langsung dibuang ke bawah..." (IK 1)

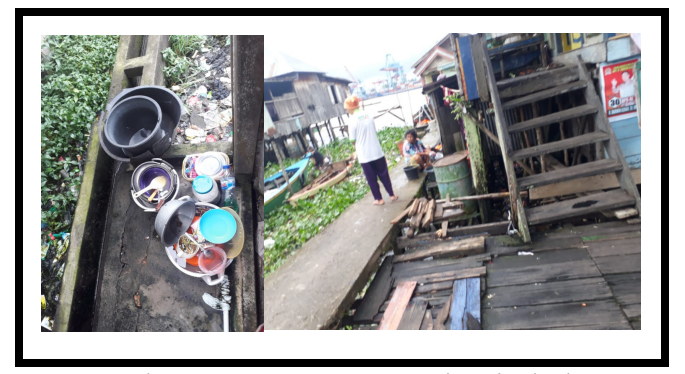

Gambar 6. Pengamanan Air Limbah RT

Penelitian ini menemukan bahwa Program STBM di lingkungan kumuh Kota Palembang masih sebatas sosialisasi tanpa ada pemicuan yang berkelanjutan. Menurut penelitian Nugraha ${ }^{6}$, pemicuan dapat berupa sosialisasi, dimana ini merupakan tahap awal dari pelaksanaan program STBM agar tujuan program yang telah ditetapkan dapat disampaikan kepada sasaran utamanya yaitu masyarakat. Pelaksanaan sosialisasi kepada masyarakat menjadi tantangan tersendiri bagi pihak yang ditunjuk karena inilah penentu apakah program tersebut tersampaikan dengan baik atau tidak dengan metode pemicuan diharapkan masyarakat lebih sadar untuk memperbaiki sarana sanitasi mereka sehingga budaya perilaku hidup bersih dan sehat pada masyarakat dapat ditingkatkan.

Pilar pertama Sanitasi Total Berbasis Masyarakat berupa Stop Buang Air Besar Sembarangan yaitu masyarakat yang ada di pinggiran sungai musi memiliki akses jamban yang langsung mengalir ke sungai dengan konstruksi kayu sebagai lantai dan seng sebagai dinding, ember kecil digunakan untuk menampung air cuci, jamban tersebut dapat berada di dalam rumah maupun diluar rumah, sedangkan yang lainnya telah memiliki jamban dengan tangki septik baik milik sendiri maupun sharing dengan konstruksi lantai kedap air baik berkeramik atau tidak dengan dinding dan atap yang kokoh dan tempat penampungan air untuk membasuh diri, namun ada juga yang berlantaikan tanah serta berdinding seng yang berada diantara rumah warga, tidak terdapat saluran air untuk disekitar jamban yang menyebabkan jika hujan jamban tersebut tergenang air. Masyarakat mengetahui tentang pentingnya kepemilikan jamban bagi keluarga dan masyarakat yang tidak tinggal di pinggiran sungai menyadari bahwa membuang air sembarangan khususnya disungai dapat merusak estetika dan lingkungan dengan kriteria jamban yang bersih, aman dan nyaman digunakan ${ }^{8}$

Menurut Peraturan Menteri Kesehatan RI Nomor 3 Tahun 2014 Kepmenkes RI ${ }^{9}$ tentang Sanitasi Total Berbasis Masyarakat pilar pertama, perilaku buang air besar sembarangan diikuti dengan pemanfaatan sarana sanitasi yang saniter berupa jamban sehat. Jamban sehat efektif untuk memutus mata rantai penularan penyakit. Standar dan persyaratan kesehatan bangunan jamban terdiri dari bangunan atas jamban (dinding dan/atau atap) berfungsi untuk melindungi pemakai dari gangguan cuaca dan gangguan lainnya, bangunan tengah jamban terdapat lubang tempat pembuangan kotoran dengan konstruksi leher angsa atau tanpa leher angsa namun diberi tutup serta lantai jamban yang kedap air dan terdapat saluran pembuanfan air limbah untuk bekas pembuangan air. Serta bangunan bawah jamban dapat berupa tangki septic atau cubluk.

Salah satu faktor yang membuat seseorang dengan mudahnya membuang air besar disungai adalah meniru apa yang dilihat dari orang tuanya dan tetangga yang melakukan hal serupa. ${ }^{10}$ Masyarakat dipinggiran sungai membuang air besar langsung kesungai dan rata-rata tidak memiliki tangki septic. ${ }^{11}$ Penggunaan tangki septik (septic tank) dan resapannya adalah salah satu cara pengelolaan tinja manusia. Dengan cara ini maka buangan yang masuk ke dalam bejana/tangki akan mengendap, terpisah antara benda cair dengan benda padatannya. Benda padatan yang mengendap di dasar tangki dalam keadaan tanpa udara, akan diproses secara anaerobic oleh bakteri sehingga kandungan organik di dalamnya akan terurai dan aman terhadap lingkungan. ${ }^{6}$

Hasil penelitian ini sejalan dengan hasil penelitian Irmalasi, Irmalasari, Najmah ${ }^{12}$ terdapat perbedaan yang signifikan mulai dari pengetahuan, sikap, dan perilaku dari masyarakat yang daerahnya telah melaksanakan STBM dan belum melaksanakan STBM terhadap perilaku buang air besar. ${ }^{8}$ Hasil penelitian ini juga sejalan dengan hasil penelitian Yulda, Fajar ${ }^{13}$ Masyarakat yang masih berlaku buang air besar sembarangan setelah mengetahui hal tersebut adalah perbuatan tidak benar, maka ia telah membuat justifikasi sendiri terhadap moral. Mereka membuat suatu perilaku buruk seolah menjadi suatu perilaku yang terlihat tidak terlalu buruk bahkan terlihat baik. Kenyataan bahwa masih ada masyarakat buang air besar di sungai. Hal ini terjadi karena perilaku tersebut telah dilakukan masyarakat dalam kurun waktu yang lama sehingga menjadi kebiasaan dan masyarakat menganggap hal ini sudah biasa dan tidak berdampak apa-apa, ditambah dengan melihat tetangga dan teman masih buang air besar di sungai seolah menjadi pembenaran atas tindakan tersebut. ${ }^{9}$

Pilar kedua Sanitasi Total Berbasis Masyarakat berupa Cuci Tangan Pakai Sabun yaitu masyarakat masih menggangap mencuci tangan dengan air saja sudah cukup walaupun mereka menyadari dampak yang akan dirasakan jika tidak mencuci tangan ataupun mencuci tangan hanya menggunakan air, waktu yang tepat untuk mencuci tangan pakai sabun yang diketahui masyarakat secara keseluruhan adalah sebelum makan dan jika mempunyai anak setelah mereka bermain selebihnya mereka mencuci tangan jika merasa tangan mereka kotor saja. Sarana cuci tangan pakai sabun yang dimiliki masyarakat tergabung dengan sarana untuk mandi dan cuci dengan air yang ditampung dalam penampungan air 
baik air sungai maupun PDAM dan menggunakan sabun mandi lalu dialirkan langsung kesungai atau tanah dan drainase. Puskesmas sendiri telah menggalakan sosialisasi terkait cuci tangan pakai sabun, dengan ditempelkannya stiker cara cuci tangan pakai sabun dan disediakan sabun diarea puskesmas agar masyarakat yang datang dapat melihat dan membaca serta mempraktekkannya, namun masih ada juga masyarakat yang tidak tahu cara mencuci tangan yang benar.

Pilar kedua, waktu yang tepat untuk melakukan cuci tangan pakai sabun adalah saat sebelum makan, sebelum mengolah dan menghidangkan makanan, sebelum menyusui, sebelum memberi makan bayi/balita, sesudah buang air besar/kecil dan sesudah memegang hewan/unggas. Cuci Tangan Pakai Sabun memiliki sarana utama yang harus terpenuhi meliputi air bersih yang dapat dialirkan, sabun dan penampungan atau saluran air limbah yang aman. ${ }^{14}$

Kebiasaan mencuci tangan hanya menggunakan air tidak dapat melindungi individu dari bakteri dan virus yang ada ditangan. Sehingga penting untuk mencuci tangan menggunakan sabun dan air mengalir. ${ }^{15}$ Mencuci tangan menggunakan sabun diketahui sebagai salah satu upaya pencegahan penyakit dan upaya pencegahan penularan penyakit. Hal ini dilakukan karena tangan merupakan agen membawa kuman dan menyebabkan patogen berpindah dari satu orang ke orang lainnya, baik dari kotak langsung mauupun tidak langsung yaitu menggunakan permukaan gelas atau handuk. ${ }^{16}$ Tangan yang kotor atau tidak dicuci menggunakan sabun pun dapat menularkan infeksi pada diri sendiri terhadap bakteri dan virus saat memegang bagian hidung, mata dan mulut. Penyakit infeksi biasanya terjangkit melalui kontak tanagn ke tangan termasuk flu dan commond cold. Pada tangan yang kurang bersih tidak hanya dapat menyebabkan ISPA dan diare tetapi juga dapat menimbulkan penyakit terkait infeksi bakteri salmonella dan e.coli. ${ }^{17}$

Hasil penelitian ini sejalan dengan hasil penelitian Musfirah, Damayanti ${ }^{18}$ Secara umum kebiasaan cuci tangan pakai sabun pada masyarakat yang rumah tangganya berpenghasilan lebih dari Rp700.000,- mempunyai risiko untuk berkebiasaan CTPS baik sebesar 0,39 kali (95\% CI: 0,20-0,76) dibandingkan masyarakat yang berpenghasilan kurang dari Rp.700.000,-, dimana ini berpengaruh terhadap kebiasaan Cuci tangan pakai sabun dan berdampak pada keberlanjutan program Sanitasi Total Berbasis Masyarakat (STBM). ${ }^{12}$ Masyarakat umumnya sudah memiliki pengetahuan yang cukup baik bahwa cuci tangan itu perlu, namun yang diperlukan adalah memicu agar masyarakat menggunakan kemampuan analisisnya dalam melihat sejauh mana cuci tangan itu perlu, mengapa harus pakai sabun dan kapan saja saat kritis untuk mencuci tangan. Metode ini diharapkan dapat membangkitkan kesadaran dan mengajak gerakan kolektif untuk bersama-sama merubah prilaku kearah yang lebih baik dengan system monitoring yang dilakukan sendiri oleh masyarakat. ${ }^{13}$

Cuci tangan adalah tindakan paling utama dan menjadi salah satu cara mencegah penularan penyakit dan tujuan utamanya secara higienis adalah untuk menghalangi transmisi kuman patogen secara cepat dan efektif. ${ }^{14}$ Sehingga penting bagi setiap individu di keluarga membiasakan untuk mencuci tangan menggunakan sabun pada saat sebelum dan sesudah melakukan aktifitas seperti makan, buang air, masak, dan lain lain. Sarana untuk cuci tangan pakai sabun pun harus diperhatikan mulai dari air, sabun hingga saluran pembuangan air limbah harus terpenuhi.

Pilar ketiga Sanitasi Total Berbasis Masyarakat berupa Pengelolaan Makanan dan Minuman Rumah ${ }^{19}$ Tangga yaitu masyarakat sangat mementingkan aspek kesehatan juga budget dalam hal memilih dan mengelola makanan masyarakat selalu membeli bahan makanan untuk dimasak setiap harinya dengan melihat kesegaran bahan dan harga, namun ada juga masyarakat yang memilih untuk membeli masakan siap saji daripada memasak. Rata-rata masyarakat melakukan pengelolaan air minum dengan mengendapkan air lalu direbus untuk diminum namun ada juga masyarakat yang menggunakan air galon dan langsung dikonsumsi. Penyimpanan makanan dan air minum sudah dilakukan dengan cara menyimpan makanan pada wadah tertutup atau dimasukkan kedalam lemari makanan juga air minum disimpan pada wadah air yang tertutup serta terdapat kran sehingga terhindar dari kontak fisik ketika mengambil air dan terhindar dari hewan atau serangga dengan mengolah sendiri makanan serta air minum untuk dikonsumsi masyarakat merasa nyaman dan sehat karena masyarakat menyadari dampak apa yang akan dirasakan bila mengolah makanan atau air minum tidak bersih.

Menurut Peraturan Menteri Kesehatan RI Nomor 3 Tahun 2014 tentang Sanitasi Total Berbasis Masyarakat pilar ketiga, pengelolaan air minum mulai dari air baku hingga air siap untuk diminum melalui perebus air sampai mendidih untuk air yang sudah jernih,koagulasi/flokulasi + desinfeksi, khlorinasi, desinfeksi dengan Sinar Matahari (SODIS) dan saringan air keramik serta memperhatikan wadah penyimpanan air yang tertutup namun mudah dibersihkan dan tidak terjangkau oleh binatang. Pengelolaan makanan mulai dari pemilihan bahan makanan harus memperhatikan mutu dan kualitas, pengolahan makanan, serta penyimpanan makanan yang disimpan dalam lemari makanan ataupun ditutup dengan tudung saji apabila disimpan diatas meja makan.

Pemilihan tempat untuk mengisi air minum isi ulang harus memperhatikan izin operasi, alat sterilisasi, sumber air baku, ruang pengisian, kebersihan DAMIU, tempat sampah, pemeriksaan bakteriologis, pakaian kerja, pelatihan penajmah makanan, pengawasan berkala, higiene personal, kebersihan diri dan fasilitas cuci tangan tidak karena 
hal ini memiliki hubungan yang bermakna dengan kualitas bakteriologis air untuk dikonsumsi. ${ }^{15}$

Kesadaran masyarakat dalam penerapan pilar ke empat tergambar dari perilaku mereka masak hingga matang terlebih dahulu sebelum diminum walaupun ada sebagian yang memilih untuk menggunakan air galon, namun tetap disimpan dalam wadah yang bersih dan aman dari jangkauan vektor, begitu juga dengan makanan masyarakat memilih membeli bahan makanan untuk satu hari dan tidak di disimpan mulai dari pemilihan bahan yang segar walaupun tetap harga menjadi pertimbangan dan pengolahan dengan cara yang bersih hingga penyimpanan makanan sendiri pada tempat yang tertutup atau dalam lemari makanan yang tertutup. ${ }^{10}$

Pilar keempat Sanitasi Total Berbasis Masyarakat berupa Pengamanan Sampah Rumah Tangga yaitu belum melakukan pengamanan sampah, mereka masih menggabungkan semua sampah untuk dibuang. Pembuangan sampah dilakukan setiap hari namun ada juga yang mengumpulkan sampah untuk dibuang sampai 2 atau 3 hari sekali, sampah dibuang langsung kesungai untuk masyarakat yang tinggal dipinggir sungai musi untuk yang lain sudah membuang sampah ke tempat pembuangan sampah. Tempat sampah yang ada dirumah pun berupa ember bekas tanpa tutup juga plastic atau karung ukuran besar yang dapat menampung banyak sampah. Tempat pembuangan sampah yang ada di daerah tanggga takat hanya ada 1 dan di daerah 16 ulu juga hanya ada 1 , petugas pengangkut sampah juga sudah disediakan oleh pemerintah setempat namun memang berbayar dan masyarakat kebanyakan memilih untuk membuang sampahnya sendiri atau membakarnya.

Pengamanan sampah dapat dilakukan mulai dari sampah yang tidak boleh ada dalam rumah dan harus dibuang setiap hari, pemilahan sampah dilakukan terhadap 2 (dua) jenis sampah, yaitu organik dan nonorganic, untuk itu perlu disediakan tempat sampah yang berbeda untuk setiap jenis sampah tersebut dan tempat sampah harus tertutup rapat, pengumpulan sampah dilakukan melalui pengambilan dan pemindahan sampah dari rumah tangga ke tempat penampungan sementara atau tempat pengolahan sampah terpadu hingga tempat pemrosesan akhir. ${ }^{9}$

Pengamanan sampah yang tidak baik akan menyebabkan pencemaran lingkungan terutama dari vektor-vektor penyakit yaitu serangga dan binatangbinatang pengerat. ${ }^{20}$ Vektor tersebut mencari makan dan berkembang biak dengan cepat sehingga dapat menimbulkan penyakit. Vektor merupakan serangga penyebar penyakit sehingga keberadaannya sangat mengganggu bagi manusia. Pengelolaan sampah berkaitan erat dengan tempat pengumpulan sampah tersebut. Konstruksi tempat sampah yang tidak kuat dan mudah bocor dapat menarik vektor seperti lalat dan atau kecoa. Tempat sampah yang tidak memenuhi syarat akan menjadi tempat yang baik bagi vector penyakit untuk mencari makanan dan berkembang biak dengan cepat sehingga mengakibatkan kejadian berbasis lingkungan di masyarakat meningkat. ${ }^{14}$

Hasil penelitian ini sejalan dengan hasil penelitian 21, 22 Masih ada masyarakat yang membuang sampah kesungai dikarenakan lebih praktis. Serta masih kurang tingkat kesadaran dan kemauan rumah tangga dalam memenuhi kebutuhan dalam manajemen pengelolaan sampah yang telah ada dengan menganggap bahwa dengan tarif retribusi yang ditetapkan masih menjadi kendala bagi responden. $^{23}$

Dalam pelaksanaan pengamanan sampah rumah tangga oleh masyarakat sebaiknya harus dibarengi dengan kepemilikan tempat sampah didalam rumah yang memenuhi syarat . Hal ini bertujuan agar menghindari dari jangkauan vektor-vektor penyakit untuk berkembang biak, seperti dari kaleng cat yang memiliki tutup sehingga mudah dibersihkan namun tetap terjaga dari jangkauan vector. Pemisahan sampah plastik dan anorganik lainnya dengan sampah organik serta tidak dibuang sembarangan dapat memberikan dampak yang baik bagi lingkungan. ${ }^{24}$

Pilar kelima Sanitasi Total Berbasis Masyarakat berupa pengamanan limbah cair rumah tangga dapat disimpulkan bahwa masyarakat langsung membuang limbah cair ke lingkungan baik secara langsung kesungai atau tanah ataupun dialirkan melalui drainase. Masyarakat yang berada di pinggiran sungai memang belum memiliki drainase sehingga mereka lebih memilih langsung membuang limbah cair ke sungai, pun dengan masyarakat yang berada jauh dari sungai yang tidak memiliki drainase memilih untuk membuang limbah cair langsung ke tanah. Pengamanan limbah cair dilakukan dengan prinsip air limbah kamar mandi dan dapur tidak boleh tercampur dengan air dari jamban, tidak menjadi tempat perindukan vector, tidak menimbulkan bau dan tidak terdapat genangan yang menyebabkan lantai licin dan rawan kecelakaan serta terhubung dengan saluran limbah umum/got atau sumur resapan. ${ }^{9}$

Pembuangan air limbah yang tidak dikelola dengan baik dan memenuhi syarat kesehatan dapat mengontaminasi lingkungan dan dijadikan sebagai tempat perindukan vektor penyakit sehingga menjadi sumber penularan penyakit, saluran pembuangan air limbah yang terbuka juga dapat menimbulkan bau serta menjadi sarana perkembang biakan vektor penyebar penyakit. ${ }^{25}$

Masyarakat dipinggiran sungai tidak memiliki saluran limbah cair sehingga langsung membuang limbah kesungai atau ketanah, sedangkan yang jauh dari sungai membuang limbah cair bekas cuci dan kamar mandi langsung ke drainase yang terbuang ke got/ selokan yang berada dekat dengan rumah responden. Lingkungan yang dekat dengan sungai membuat masyarakat merasa tidak perlu membuat saluran pembuangan air limbah karena limbah bekas cucian mereka akan langsung terbawa oleh sungai, sedangkan yang telah memiliki drainase dan got yang jaraknya tidak jauh dari rumah merasa tidak perlu 
membuat saluran pembuanngan air limbah. Limbah cair yang menggenang di lingkungan rumah akan menjadi sarang yang baik untuk vektor penyakit berkembang biak.

\section{SIMPULAN}

Pilar-pilar STBM yang dilaksanakan di daerah tersebut belum maksimal seperti pilar pertama stop buang air besar sembarangan untuk konstruksi jamban yang dimiliki masyarakat khususnya masyarakat yang tinggal dipinggir sungai mereka menggunakan jamban cemplung dengan lantai dan dinding kayu. Pilar kedua yaitu cuci tangan pakai sabun masyarakat belum menganggap mencuci tangan pakai sabun dan air itu penting, mereka berfikir cukup menggunakan air saja. Pilar keempat yaitu pengamanan sampah rumah tangga, masyarakat menggabungkan sampah menjadi satu untuk dibuang setiap hari atau 2 sampai 3 hari sekali didalam plastic besar untuk dibuang ketempat sampah, kesungai atau dibakar.

Serta pilar kelima pengamanan air limbah rumah tangga, masyarakat langsung membuang air limbah tersebut kesungai, tanah, ataupun drainase. Hal ini dikarenakan masyarakat belum mengetahui mengenai STBM serta mereka belum mendapatkan sosialiasi ataupun pemicuan terkait STBM, masyarakat yang daerahnya sudah mendapatkan sosialiasi STBM pun belum mengetahui mengenai STBM karena sosialiasi hanya diberikan kepada pemuka masyarakat dan kader saja seharusnya sosialisasi atau pemicuan dapat langsung dilaksanakan dengan melibatkan masyarakat untuk memicu rasa ingin merubah kebiasaan buruk dari mereka sendiri. Namun ada juga masyarakat yang telah sadar untuk melaksanakan pilar STBM karena mereka merasa itu penting untuk kesehatan mereka sendiri tanpa adanya metode pemicuan terlebih dahulu.

\section{DAFTAR PUSTAKA}

1. Nugraha MF. Dampak Program Sanitasi Total Berbasis Masyarakat (STBM) Pilar Pertama di Desa Gucialit Kecamatan Gucialit Kabupaten Lumajang. Universitas Airlangga. 2015.

2. Kepmenkes RI. Strategi Nasional Sanitasi Total Berbasis Masyarakat Nomor 852/Menkes/SK/IX/2008. Jakarta: Kementrian Kesehatan Republik Indonesia; 2008.

3. Kemenkes RI. Profil kesehatan Indonesia tahun 2014. Jakarta: Kementerian Kesehatan Republik Indonesia, 20156022359112.

4. Budi IS, Ardillah Y, Sari IP, Septiawati D. Analisis Faktor Risiko Kejadian penyakit Tuberculosis Bagi Masyarakat Daerah Kumuh Kota Palembang. Jurnal Kesehatan Lingkungan Indonesia. $2018 ; 17(2): 87-$ 94.https://doi.org/10.14710/jkli.17.2.87-94

5. Ardillah Y, Sari IP, Windusari Y, editors. Association of Environmental Residential Sanitation Factors to Communicable Disease Risk Among Musi Side-River Household in Palembang,
Indonesia: A Study of Slum Area. 2nd Sriwijaya International Conference of Public Health (SICPH 2019); 2020: Atlantis Press.https://doi.org/10.2991/ahsr.k.200612.021

6. Nugraha MF. Dampak Program Sanitasi Total Berbasis Masyarakat (STBM) Pilar Pertama di Desa Gucialit Kecamatan Gucialit Kabupaten Lumajang. Surabaya: Universitas Airlangga; 2015.

7. Crocker J, Saywell D, Bartram J. Sustainability of community-led total sanitation outcomes: Evidence from Ethiopia and Ghana. International Journal of Hygiene and Environmental Health. 2017;220(3):551-

7.https://doi.org/10.1016/j.ijheh.2017.02.011

8. Fanucchi MV. Drinking Water and Sanitation. In: Quah SR, editor. International Encyclopedia of Public Health (Second Edition). Oxford: Academic Press; 2017. p. 35060.https://doi.org/10.1016/B978-0-12-8036785.00118-1

9. Kepmenkes RI. Sanitasi Total Berbasis Masyarakat. Nomor 3 Tahun 2014. Jakarta: Kementrian Kesehatan RI; 2014.

10. Carter RC. Can and should sanitation and hygiene programmes be expected to achieve health impacts? Waterlines. 2017;36(1):92103.https://doi.org/10.3362/1756-3488.2017.005

11.Bardosh K. Achieving "Total Sanitation" in Rural African Geographies: Poverty, Participation and Pit Latrines in Eastern Zambia. Geoforum. 2015;66:53-

63.https://doi.org/10.1016/j.geoforum.2015.09.004

12. Irmalasari R, Najmah N, Fajar NA. Studi komporatif, Perilaku Buang Air Besar yang Telah dan Belum Melaksanakan Sanitasi Total Berbasis Masyarakat di Kecamatan Indralaya Utara. Jurnal Ilmu Kesehatan Masyarakat. 2011;2(3).

13. Yulda A, Fajar NA, Utama F. Pengaruh Faktor Internal dan Eksternal Terhadap Perilaku Buang Air Besar di Jamban Pasca Pemicuan di Wilayah Kerja Puskesmas Tanjung Batu. Jurnal Ilmu Kesehatan Masyarakat. 2017;8(2).

14. Astuti FD, Rokhmayanti R, editors. Pengelolaan sampah sebagai pencegahan penyakit tular vektor. Seminar Nasional Hasil Pengabdian Kepada Masyarakat; 2019.

15. Kasjono HS, Widyantoro W, Pujiyati NE. Model Pemberdayaan Masyarakat Dalam Melaksanakan 5 Pilar STBM Di Sorowajan Bantul. Aksiologiya: Jurnal Pengabdian Kepada Masyarakat. 2017;1(2):142-

50.https://doi.org/10.30651/aks.v1i2.938

16. Krishnan S. Water, sanitation and hygiene (WASH) and disaster recovery for community resilience: A mixed methods study from Odisha, India. International Journal of Disaster Risk Reduction.

2019;35:101061.https://doi.org/10.1016/j.ijdrr.201 8.12 .023 
17. Murwani S. Dasar-Dasar Mikrobiologi Veteriner: Universitas Brawijaya Press; 2015.

18. Musfirah M, Damayanti GR, Wardani NO, Putri MZC, Savitri S, Salsabila AN, et al. Pemicuan STBM Pilar CTPS Pada Masyarakat Di Dusun Pringgolayan. Jurnal Pemberdayaan: Publikasi Hasil Pengabdian Kepada Masyarakat. 2020;4(2):211-8.

19. Bisung E, Dickin S. Concept mapping: Engaging stakeholders to identify factors that contribute to empowerment in the water and sanitation sector in West Africa. SSM - Population Health. 2019;9:100490.https://doi.org/10.1016/j.ssmph.20 19.100490

20.Freeman MC, Garn JV, Sclar GD, Boisson S, Medlicott K, Alexander KT, et al. The impact of sanitation on infectious disease and nutritional status: A systematic review and meta-analysis. International Journal of Hygiene and Environmental Health. 2017;220(6):92849.https://doi.org/10.1016/j.ijheh.2017.05.007

21. Arfiah A, Patmawati P, Afriani A. Gambaran Pelaksanaan Sanitasi Total Berbasis Masyarakat (STBM) Di Desa Padang Timur Kecamatan Campalagian Kabupaten Polewali Mandar. JKESMAS: Jurnal Kesehatan Masyarakat. 2019;4(2):113-

35.https://doi.org/10.35329/jkesmas.v4i2.253

22. Octavia YT, Munte SA, Jusniar E. Gambaran Pelaksanaan Sanitasi Total Berbasis Masyarakat (STBM) di Kelurahan Sri Padang Kecamatan Rambutan Kota Tebing Tinggi Tahun 2019. Jurnal Riset Hesti Medan Akper Kesdam I/BB Medan. 2020;5(1):1-

9.https://doi.org/10.34008/jurhesti.v5i1.176

23. Oktaria F, Ardillah Y. Hubungan Hygiene Dan Sanitasi Dengan Kejadian Diare Pada Balita Di Pinggiran Sungai Musi Seberang Ulu Ii Palembang Indralaya: Sriwijaya University; 2019.

24.Zurbrügg C, Gfrerer M, Ashadi H, Brenner W, Küper D. Determinants of sustainability in solid waste management - The Gianyar Waste Recovery Project in Indonesia. Waste Management. 2012;32(11):2126-

33.https://doi.org/10.1016/j.wasman.2012.01.011

25. Sulistiyorini NR, Darwis RS, Gutama AS. Partisipasi masyarakat dalam pengelolaan sampah di lingkungan Margaluyu Kelurahan Cicurug. SHARE: Social Work Journal. 2015;5(1).https://doi.org/10.24198/share.v5i1.131 20 